\title{
THE CULTURE OF CLINICAL SPECIMENS FOR ANAEROBIC BACTERIA : A COMPARISON OF THREE REGIMENS
}

\author{
M. W. D. WREN \\ Department of Microbiology, North Middlesex Hospital, Edmonton, London, NI8 1QX
}

IN recent years, new systems have been devised for the anaerobic culture of clinical specimens. One of the most recent developments has been the use of an anaerobic chamber, so that-when used in combination with efficient transport-neither specimens nor culture media are exposed to atmospheric oxygen. Some workers have indicated that such chambers are necessary for the efficient isolation of anaerobic bacteria (Drasar, 1967; Spears and Freter, 1967; Vargo et al., 1971; Peach and Hayek, 1974), whereas others have found them of no advantage (Killigore et al., 1973; Rosenblatt, Fallon and Finegold, 1973; Spaulding et al., 1974; Watt, Collee and Brown, 1974).

This paper presents the results of a comparative study of three culture regimens used for the anaerobic culture of clinical specimens submitted for bacteriological investigation: (i) the routine bench technique in current use in this laboratory; (ii) a 48-h primary plating regimen; and (iii) an anaerobic chamber of the flexible type as described by Aranki et al. (1969).

\section{MATERIALS AND METHODS}

Specimens and transport. Specimens received for culture were either fluid pus or swabs of purulent material from patients with peritonitis (6), various abdominal abscesses (10), empyema (5), breast abscess (1) and superficial abscesses (3). Pus samples aspirated from patients in the operating theatre were placed into sterile MacCartney's bottles and delivered directly to the laboratory. Swabs of purulent material were immediately placed into long narrow screw-capped tubes containing a column of pre-reduced Cary and Blair transport medium at least $8 \mathrm{~cm}$ in height (Cary and Blair, 1964).

Media. None of the media used was sterilised under anaerobic conditions, and only the plating media used in the chamber technique were stored anaerobically. Blood agar was prepared by adding defibrinated horse blood to Columbia Agar Base (London Analytical and Bacteriological Media Ltd, Salford, Lancs.) at a final concentration of $5 \%$. Kanamycinbrucella agar was prepared by adding kanamycin $75 \mu \mathrm{g}$ per $\mathrm{ml}$ (Bristol Laboratories, Langley, Bucks.) to Brucella Agar (Difco Laboratories, West Molesey, Surrey) which had been supplemented with defibrinated horse blood $5 \%$ and menadione (Sigma Chemical Co. Ltd, Kingston-upon-Thames, Surrey) at $\mathbf{0 . 5} \mu \mathrm{g}$ per ml. MacConkey's Agar was obtained as pre-poured plates from London Analytical and Bacteriological Media Ltd. GlucoseCooked-Meat Broth was obtained as a complete medium from Southern Group Laboratories, Lewisham, London. Brucella-blood agar was prepared by adding defibrinated horse blood $(5 \%)$ and menadione $(0.5 \mu \mathrm{g}$ per $\mathrm{ml})$ to Brucella Agar. Egg-yolk agar was made by adding $2 \mathrm{ml}$ egg-yolk emulsion (Oxoid Ltd, Basingstoke, Hants.) to $18 \mathrm{ml}$ of Nutrient Agar (Southern Group Laboratories).

Identification media. Thioglycollate medium was prepared by adding haemin (B.D.H. Ltd, Poole, Dorset), menadione and sodium bicarbonate (Hopkin and Williams) to Brewer's

Received 10 Aug. 1976; revised version accepted 27 Sept. 1976. 
Thioglycollate Medium (Southern Group Laboratories) at final concentrations of $5 \mu \mathrm{g}$ per $\mathrm{ml}$, $0.5 \mu \mathrm{g}$ per $\mathrm{ml}$, and $1 \mathrm{mg}$ per $\mathrm{ml}$ respectively. The basal medium for carbohydrate-fermentation studies was that of Holdeman and Moore (1972), and when used for fermentation studies of the anaerobic gram-positive cocci it contained Tween 80 (Sigma Chemical Co.) at a final concentration of $0.1 \%$. The carbohydrates used for fermentation studies were the same as listed by Holdeman and Moore (1972) for each particular genus. Indole Nitrite Broth was prepared from the commercial dehydrated product according to the manufacturer's instructions (Beckton-Dickinson Ltd, Wembley, Middlesex).

Culture regimens. On receipt of the specimen in the laboratory the material for culture was passed into the anaerobic chamber and part of the sample was processed by the chamber regimen. The specimen was then removed from the chamber and cultured by the remaining two regimens at the bench. After culturing the specimen by all three systems a direct smear was made from the material and stained by Gram's method to observe the number and proportion of morphological types present.

Anaerobic chamber. The anaerobic chamber used was of the flexible plastic type with two arm ports and an opaque flooring (Plysu Industrial Ltd, Bletchley, Bucks.). The internal atmosphere of the chamber was isolated from the air by an air-lock system constructed from two small autoclaves by the engineering department of this hospital. The chamber was maintained under anaerobic conditions by the admission of a gas mixture containing $90 \%$ nitrogen and $10 \%$ hydrogen (British Oxygen Company, Special Gases Division, London) and circulated throughout the chamber by the action of a small fan blowing over a wire-mesh envelope holding $1 \mathrm{~kg}$ of Cold Catalyst D (Englehard Industries Ltd, Cinderford, Gloucestershire). A small tray of silica gel (Hopkin and Williams, Romford, Essex) was also included to remove moisture formed by the action of the catalyst. Catalyst pellets were changed at weekly intervals and reactivated by heating in a hot-air oven at $160^{\circ} \mathrm{C}$ for $2 \mathrm{~h}$. Gas was replenished in the chamber by the process of evacuating and filling the air lock.

Specimens taken into the chamber were cultured by plating a large loopful of pus on to a blood-agar plate and a kanamycin-brucella-agar plate. Pus $(1 \mathrm{ml})$ was also placed into a bottle of glucose-cooked-meat broth. After plating, the blood-agar and kanamycin-brucella-agar plates were placed into a steel anaerobic jar (Stuart Scientific Co., Croydon, Surrey) and the jar closed and tightened while still within the chamber. The jar was then removed from the chamber and evacuated, and the gas mixture replaced with another containing $90 \%$ hydrogen and $10 \%$ carbon dioxide. The jars were fitted with a modified catalyst sachet (Baldwin, 1975) holding $8.5 \mathrm{~g}$ of Cold Catalyst $\mathrm{D}$ and were processed in the manner recommended by Watt and Collee (1974). All jars were incubated at $37^{\circ} \mathrm{C}$ and all subsequent readings of the plates were made within the chamber. Swabs of purulent material were treated similarly but a glucose-cooked-meat broth was not inoculated. All media used in the chamber regimen were prestored within the chamber for $48 \mathrm{~h}$ before use. Loops and straight wires were sterilised by inserting them into a small " micro-incinerator " constructed from a small electrical fire bar connected to a variable transformer (with suitable precautions to protect the operator).

The chamber atmosphere was monitored by checking its ability to support the growth of Clostridium tetani strain NCTC9569 when streaked on blood agar and incubated in an anaerobic jar containing the chamber atmosphere and without a catalyst. No other types of measurement were made.

Conventional bench regimen. A large loopful of pus was plated on to two blood-agar plates, one plate of kanamycin-brucella agar, and one MacConkey's-agar plate. One bloodagar and the MacConkey's-agar plate were incubated aerobically. The second blood-agar and the kanamycin-brucella-agar plate were incubated anaerobically in anaerobic jars according to the method of Watt and Collee (1974). Jars were fitted with the modified catalyst sachet described above and were filled with the gas mixture as described above. Pus $(1 \mathrm{ml})$ was placed into a bottle of glucose-cooked-meat broth which was incubated aerobically.

Forty-eight-hour primary plating regimen. The specimens in this regimen were plated exactly in the same manner as that for the conventional bench regimen, but the primary anaerobic plates were left incubating in the anaerobic jars for $48 \mathrm{~h}$ before the initial examination. 
Reading of plates. Aerobic plates were read at $24 \mathrm{~h}$ and organisms picked off and identified at this time. Anaerobic-chamber plates were read at daily intervals within the chamber and organisms were picked off and identified as they appeared. Plates incubated anaerobically by the conventional bench regimen were read at $24 \mathrm{~h}$ and at $48 \mathrm{~h}$. They were then re-incubated for 3 more days and finally read after 5 days. Plates in the 48-h regimen were read at $48 \mathrm{~h}$ and at $72 \mathrm{~h}$. Final readings were made after anaerobic incubation for 2 more days. Organisms in the two bench routines were picked off and identified as they became apparent on examination of plate media.

Cultures in glucose-cooked-meat broth. Bottles of the medium were stored in the chamber for $72 \mathrm{~h}$ before use in the chamber regimen or were placed in a boiling water bath (with the caps loosened) for $30 \mathrm{~min}$. and then cooled (with caps tightened) to remove dissolved oxygen. Inoculated glucose-cooked-meat broths were incubated for $48 \mathrm{~h}$ and then subcultured on to kanamycin-brucella agar for anaerobic incubation and to blood agar and MacConkey's agar for aerobic incubation. The kanamycin-brucella-agar plates were incubated in anaerobic jars for 3 days before examination.

Identification of facultative bacteria. All aerobic and facultative bacteria were identified by the methods outlined by Cowan (1974).

Identification of anaerobic bacteria. Colonies of suspected anaerobic bacteria were tested for their atmospheric requirements by plating one colony on to two brucella-blood-agar plates-one incubated anaerobically and the other in an atmosphere of air plus $10 \%$ carbon dioxide. After incubation for $48 \mathrm{~h}$, organisms growing only on the anaerobic plate were identified by the anaerobic techniques given below. Organisms growing on both plates were assumed to be microaerophilic and were identified by conventional tests.

Identification tests. Anaerobic gram-negative bacilli were assigned to the genus Bacteroides or Fusobacterium by antimicrobial sensitivity or resistance patterns as published by Sutter, Vargo and Finegold (1975). These patterns together with other simple biochemical tests listed by these workers allowed us to identify Bacteroides fragilis, B. melaninogenicus, $B$. corrodens, Fusobacterium necrophorum, F. mortiferum, and F. nucleatum. Gram-negative anaerobic bacilli that did not fall into these defined species were termed Bacteroides sp. or Fusobacterium sp.

Anaerobic gram-positive cocci were identified by biochemical fermentation tests (Holdeman and Moore, 1972) and by morphological characteristics noted in wet preparations from 24-h thioglycollate cultures examined under phase-contrast microscopy with a Watson Hilux 70 microscope with Phase 70 fittings (M.E.L. Equipment Co. Ltd, Watson Microscope Division, Barnet, Herts).

Gram-negative cocci were identified by biochemical characteristics (Holdeman and Moore, 1972), morphology under phase-contrast microscopy, and by the catalase test performed on 48-h cultures on egg-yolk agar.

Clostridium welchii was identified on the basis of specific neutralisation of lecithinase activity on egg-yolk agar by commercial $C$. welchii type-A antitoxin (Wellcome Laboratories, Beckenham, Kent) together with other biochemical tests listed by Sutter et al. (1975).

Anaerobic gram-positive bacilli that failed to poduce spores in glucose-cooked-meat medium incubated at $30^{\circ} \mathrm{C}$ for up to 3 weeks were designated " anaerobic non-sporing gram-positive bacilli " and were not identified further.

\section{RESULTS}

In all, 20 samples of liquid pus and five pus swabs in Cary and Blair transport medium were examined in this study. All pus samples were aspirated from closed abscesses or pus-filled cavities in patients undergoing surgery. Swabs were taken after incision of an abscess or opening of a cavity. Sixteen samples originated from the abdominal region, six from the thorax, and three from superficial sites. These 25 specimens were selected on the basis of the site of infection and on the associated likelihood of finding anaerobic bacteria in 
TABLE I

Distribution of genera

\begin{tabular}{l|cccc}
\hline Genus or group & $\begin{array}{c}\text { Total number } \\
\text { and percentage) } \\
\text { isolated by } \\
\text { any procedure }\end{array}$ & $\begin{array}{c}\text { Number of isolates obtained by } \\
\text { conventional } \\
\text { procedure }\end{array}$ & $\begin{array}{c}48-\mathrm{h} \\
\text { procedure }\end{array}$ & $\begin{array}{c}\text { chamber } \\
\text { procedure }\end{array}$ \\
\hline Bacteroides & $36(40 \cdot 4)$ & 19 & 36 & 35 \\
Fusobacterium & $9(10.1)$ & 0 & 9 & 8 \\
$\begin{array}{l}\text { Peptococcus } \\
\text { Peptostreptococcus }\end{array}$ & $18(20 \cdot 2)$ & 10 & 16 & 17 \\
Clostridium & $7(7 \cdot 8)$ & 1 & 7 & 6 \\
NSGPB & $2(2 \cdot 2)$ & 2 & 2 & 2 \\
Veillonella & $12(13.4)$ & 1 & 12 & 11 \\
Totals & $5(5 \cdot 6)$ & 0 & 5 & 4 \\
\hline & $89(100)$ & 33 & 87 & 83 \\
\hline
\end{tabular}

* NSGPB = non-sporing gram-positive bacilli.

them. All of the pus samples had a foul odour, and all contained anaerobic bacteria ranging from one to eight strains per specimen. From 14 of the samples, a concurrent growth of facultative bacteria was obtained, but in these specimens anaerobes outnumbered facultative bacteria by a ratio of 3.9 to 1 . The remaining 11 specimens contained anaerobes only; four yielded pure cultures of a single anaerobic bacterium: Peptococcus prevotii (neck abscess), $B$. fragilis (uterine pus), B. fragilis (laparotomy wound) and $F$. necrophorum (peritoneal pus). The other seven samples contained mixtures of anaerobes totalling 22 strains.

A total of 89 anaerobes (table I) and 16 facultative and microaerophilic bacteria were cultured from the 25 specimens when all of the methods were applied. The conventional bench procedure isolated 33 strains of anaerobic bacteria, the 48-h primary plating regimen isolated 87 anaerobes, and the anaerobic chamber procedure yielded 83 strains (tables I and II).

It was found that most genera benefited from the prolonged incubation period-particularly Bacteroides species, fusobacteria, veillonellae and nonsporing gram-positive bacilli (table II). The isolation rates obtained with the 48-h regimen and the anaerobic chamber were comparable. Two strains were isolated with the chamber regimen only, and six with the 48-h regimen only.

The most common anaerobe was $B$. fragilis, which accounted for $19 \%$ of the total number of strains; B. melaninogenicus accounted for $11.2 \%$ of the total. Bacteroides was the most common genus, accounting for $40.4 \%$ of all anaerobes isolated (table I). In all, $50 \%$ of the isolates were anaerobic gramnegative bacilli and a further $33.6 \%$ of the strains were anaerobic cocci.

\section{Discussion}

Earlier work in this laboratory revealed that significantly greater numbers of anaerobic bacteria can be recovered from clinical specimens cultured on 
TABLE II

Distribution of species

\begin{tabular}{|c|c|c|c|c|c|}
\hline & & & Total & umber isolat & \\
\hline Micro-organism & isolated & $\begin{array}{l}\text { isolated by } \\
\text { any procedure }\end{array}$ & $\begin{array}{c}\text { conventional } \\
\text { procedure }\end{array}$ & $\begin{array}{c}\text { 48-h } \\
\text { procedure }\end{array}$ & $\begin{array}{l}\text { chamber } \\
\text { procedure }\end{array}$ \\
\hline Anaerobic species o & $r$ group & & & & \\
\hline Bacteroides $\left\{\begin{array}{l}\text { fragil } \\
\text { melar } \\
\text { corro } \\
\text { other }\end{array}\right.$ & $\begin{array}{l}\text { is } \\
\text { inogenicus } \\
\text { dens } \\
\text { species }\end{array}$ & $\begin{array}{r}17 \\
10 \\
1 \\
8\end{array}$ & $\begin{array}{r}12 \\
5 \\
0 \\
2\end{array}$ & $\begin{array}{r}17 \\
10 \\
1 \\
8\end{array}$ & $\begin{array}{r}17 \\
10 \\
1 \\
7\end{array}$ \\
\hline Fusobacterium $\left\{\begin{array}{l}m c \\
n e \\
n u \\
\text { ot }\end{array}\right.$ & $\begin{array}{l}\text { rtiferum } \\
\text { crophorum } \\
\text { cleatum } \\
\text { ier species }\end{array}$ & $\begin{array}{l}2 \\
3 \\
2 \\
2\end{array}$ & $\begin{array}{l}\mathbf{0} \\
\mathbf{0} \\
\mathbf{0} \\
\mathbf{0}\end{array}$ & $\begin{array}{l}2 \\
3 \\
2 \\
2\end{array}$ & $\begin{array}{l}2 \\
2 \\
2 \\
2\end{array}$ \\
\hline Peptococcus $\left\{\begin{array}{l}\text { asacc } \\
\text { prevo } \\
\text { magr } \\
\text { morb } \\
\text { other }\end{array}\right.$ & $\begin{array}{l}\text { harolyticus } \\
\text { tii } \\
\text { us } \\
\text { illorum } \\
\text { species }\end{array}$ & $\begin{array}{l}5 \\
4 \\
2 \\
1 \\
6\end{array}$ & $\begin{array}{l}3 \\
1 \\
1 \\
1 \\
4\end{array}$ & $\begin{array}{l}5 \\
4 \\
2 \\
1 \\
4\end{array}$ & $\begin{array}{l}4 \\
4 \\
2 \\
1 \\
6\end{array}$ \\
\hline Peptostreptococcus & $\left\{\begin{array}{l}\text { anaerobius } \\
\text { intermedius } \\
\text { micros } \\
\text { other } \\
\text { species }\end{array}\right.$ & $\begin{array}{l}2 \\
1 \\
1 \\
3\end{array}$ & $\begin{array}{l}0 \\
1 \\
0 \\
0\end{array}$ & $\begin{array}{l}2 \\
1 \\
1 \\
3\end{array}$ & $\begin{array}{l}2 \\
1 \\
0 \\
3\end{array}$ \\
\hline $\begin{array}{l}\text { Clostridium welchii } \\
\text { NSGPB* } \\
\text { Veillonella parvula }\end{array}$ & & $\begin{array}{r}2 \\
12 \\
5\end{array}$ & $\begin{array}{l}2 \\
1 \\
0\end{array}$ & $\begin{array}{r}2 \\
12 \\
5\end{array}$ & $\begin{array}{r}2 \\
11 \\
4\end{array}$ \\
\hline Total anaerobes & & 89 & 33 & 87 & 83 \\
\hline $\begin{array}{l}\text { Aerobic species or } \\
\text { Escherichia coli } \\
\text { Microaerophilic str } \\
\text { Haemolytic strepto } \\
\text { "Viridans" strepto } \\
\text { Proteus morgani } \\
\text { Proteus vulgaris } \\
\text { Pseudomonas aerug } \\
\text { Shigella sonnei }\end{array}$ & $\begin{array}{l}\text { roup } \\
\text { eptococci } \\
\text { cocci } \\
\text { occi } \\
\text { inosa }\end{array}$ & $\begin{array}{l}6 \\
3 \\
2 \\
1 \\
1 \\
1 \\
1 \\
1\end{array}$ & $\begin{array}{l}6 \\
3 \\
2 \\
1 \\
1 \\
1 \\
1 \\
1\end{array}$ & $\begin{array}{l}\cdots \\
\cdots \\
\cdots \\
\cdots \\
\cdots \\
\cdots \\
\cdots\end{array}$ & $\begin{array}{l}\ldots \\
\cdots \\
\cdots \\
\cdots \\
\cdots \\
\cdots \\
\ldots\end{array}$ \\
\hline Total aerobes & & 16 & 16 & $\ldots$ & $\ldots$ \\
\hline
\end{tabular}

$\ldots=$ Not recorded.

$\dddot{*}$ NSGPB $=$ Non-sporing gram-positive bacilli.

primary anaerobic plates if the plates are incubated for $48 \mathrm{~h}$ rather than $24 \mathrm{~h}$ before being examined for the first time (Wren et al., 1977).

In the present study, the prolonged incubation afforded by the 48-h regimen led to the isolation of 2.6 times the number of anaerobic bacteria obtained by the conventional 24-h system. Early exposure to air of micro-colonies forming on the agar surface, and their subsequent death, may account for the low rate 
of isolation in the conventional regimen. The chamber regimen provided continuous anaerobic conditions and yielded the same isolation rate as the 48-h system.

The data presented show that most anaerobic genera benefit from a longer primary incubation period, particularly Fusobacterium, Bacteroides, Veillonella and the non-sporing gram-positive bacilli; many species showed a large improvement in isolation-for example a two-fold rise in the numbers of $B$. melaninogenicus, a four-fold rise in a number of Bacteroides species and a fivefold rise in Veillonella parvula.

The use of the anaerobic chamber together with pre-reduced media has been recommended for the isolation of anaerobes from clinical material (McMinn and Crawford, 1970; Vargo et al., 1971; Peach and Hayek, 1974). The present study shows that, when specimens are rapidly transported to the laboratory, the use of an anaerobic chamber does not improve the yield of anaerobes, particularly when primary plates are incubated for $48 \mathrm{~h}$ before being read.

In the comparative studies that lent support to the use of an anaerobic chamber, there were differences in the methods of specimen transport, the duration of incubation, and the gaseous environments used with the various anaerobic systems. The studies by Killigore et al. (1973) and Rosenblatt et al. (1973) both showed that, when specimens were carefully collected and transported, and when cultures were incubated anaerobically for $48 \mathrm{~h}$ before being read, comparable isolation rates for clinically significant anaerobes were obtained by jar or chamber procedures. Similarly, in the study by Spaulding et al. (1974), initial indications were that an anaerobic chamber procedure was superior; but when differences in the systems compared were standardised, these workers found that routine and chamber procedures were equally effective. When comparing 24-h and 48-h anaerobic plates in their study, Spaulding and his colleagues found 2.8 times more anaerobes on the 48-h plates than on 24-h plates. The findings in the present study are very similar.

One British team have found that bench techniques are as effective as the use of a chamber for the isolation of exacting anaerobes and for isolating anaerobes from fresh faeces of healthy persons (Watt et al., 1974). These workers were consequently reluctant to accept the view that chambers are necessary for anaerobic work; our results with clinical specimens support their findings.

Although anaerobic chambers provide an effective means of isolating anaerobic bacteria, this study indicates that it is not the use of chambers but an improvement in bench technique that is primarily required to achieve good results with clinical specimens that are submitted properly for anaerobic culture.

\section{SUMMARY}

Three procedures for the anaerobic culture of clinical specimens are compared: (i) a conventional bench routine, (ii) a system whereby primary anaerobic plates were incubated for $48 \mathrm{~h}$ before examination, and (iii) an anaerobic chamber. 
It was shown that the anaerobic chamber was of no advantage over bench regimens when primary anaerobic plates were incubated for $48 \mathrm{~h}$ before being examined.

The help of Mrs G. Browse, Control of Infection Sister, is gratefully acknowledged for the prompt delivery of many of the specimens. I also wish to thank Mr Alan Baldwin for the construction of the " micro-incinerator" used in the chamber studies, and Dr P. J. Sanderson for his encouragement during the greater part of this study.

\section{REFERENCES}

Aranki, A., Syed, S. A., Kenney, E. B. AND Freter, R. 1969. Isolation of anaerobic bacteria from human gingiva and mouse caecum by means of a simplified glove box procedure. Appl. Microbiol., 17, 568.

Baldwin, A. W. F. 1975. An improved catalyst sachet for anaerobic jars. Med. Lab. Technol., 32, 329.

CARY, S. G. AND Blair, E. B. 1964. New transport medium for the shipment of clinical specimens. I. Fecal specimens. J. Bact., 88, 96.

Cowan, S. T. 1974. Cowan and Steele's Manual for the identification of medical bacteria, 2nd ed., London.

Drasar, B. S. 1967. Cultivation of anaerobic intestinal bacteria. J. Path. Bact., 94, 417.

Holdeman, L. V. ANd Moore, W. E. C. 1972. Anaerobe Laboratory Manual, 2nd ed., Blacksburg, Virginia.

Killigore, G. E., Starr, S. E., Del Bene, V. E., Whaley, D. N. and Dowell, V. R. JR. 1973. Comparison of three anaerobic systems for the isolation of anaerobic bacteria from clinical specimens. Am. J. clin. Path., 59, 552.

MCMinN, M. T. AND CRAwFORD, J. J. 1970. Recovery of anaerobic microorganisms from clinical specimens in prereduced media versus recovery by routine clinical laboratory methods. Appl. Microbiol., 19, 207.

PEACH, S. AND HAYEK, L. 1974. The isolation of anaerobic bacteria from wound swabs. J. clin. Path., 27, 578.

Rosenblatt, J. E., Fallon, A. and Finegold, S. M. 1973. Comparison of methods for isolation of anaerobic bacteria from clinical specimens. Appl. Microbiol., $25,77$.

Spaulding, E. H., Vargo, V., Michaelson, T. C. and Swenson, R. M. 1974. A comparison of two procedures for isolating anaerobic bacteria from clinical specimens. In Anaerobic bacteria: role in disease, edited by A. Balows, R. M. DeHaan, V. R. Dowell and L. B. Guze, Springfield, Illinois, p. 37.

SPEARS, R. AND FRETER, R. 1967. Improved isolation of anaerobic bacteria from the mouse caecum by maintaining continuous strict anaerobiosis. Proc. Soc. exp. Biol. Med., 124, 903.

SutTer, V. L., VARgo, V. AND Finegold, S. M. 1975. Wadsworth Anaerobic Bacteriology Manual, 2nd ed., Department of Continuing Education in Health Sciences, University Extension, Los Angeles.

Vargo, V., Michaelson, T. C., Spaulding, E. H., Vitagliano, R., Swenson, R. M. and Forsch, E. 1971. Comparison of pre-reduced anaerobic methods and Gas-Pak for isolating anaerobic bacteria. Bact. Proc., p. 109.

Watt, B. AND COLlee, J. G. 1974. Practical approaches to the isolation and identification of clinically important non-sporing anaerobes. In Infection with non-sporing anaerobic bacteria, edited by I. Phillips and M. Sussman, London, p. 7.

Watt, B., Collee, J. G. AND BRown, R. 1974. The isolation of strict anaerobes: the use of an anaerobic cabinet compared with a conventional procedure. J. med. Microbiol., 7, 315.

Wren, M. W. D., Baldwin, A. W. F., Eldon, C. P. and Sanderson, P. J. 1977. The anaerobic culture of clinical specimens: a 14 month study. J. med. Microbiol., 10, 49. 